\title{
Use of specific DNA probes for the rapid characterization of yeasts isolated from complex biotopes
}

\author{
Anne-Marie Davila, Monique Diez, Mauricio Corredor, \\ Yves Pagot, Michèle Winkler, Claude Gaillardin, \\ Serge CASAREgOlA* \\ ${ }^{\text {a }}$ Collection de levures d'intérêt biotechnologique, Génétique moléculaire et \\ cellulaire, Cnrs URA1925, Inra UMR216, Institut national agronomique \\ Paris-Grignon, 78850 Thiverval-Grignon, France
}

\begin{abstract}
We describe a rapid method developed to identify yeast species commonly found during cheese ripening. It is based on the isolation of species-specific sequences and their hybridization with coarse preparations of genomic DNA. Several strategies were followed for the construction of probes: PCR amplification of sequences available in databases, random cloning of genomic DNA fragments, specific RAPD fragments and PCR-amplified ribosomal DNA fragments. After validation, the probes were applied to the characterization of 400 yeast strains isolated from various French cheeses. Since the strains had been previously identified with classical diagnostic tests, we were able to compare molecular and conventional identification. In addition, the specific probes for one of the species, Debaryomyces hansenii, were used successfully in colony hybridization experiments. The probes developed here proved to be very useful for the screening of large yeast collections and for the assessment of biodiversity within the yeast flora in cheese.
\end{abstract}

yeast / cheese / molecular identification / hybridization / biodiversity

Résumé - Utilisation de sondes ADN spécifiques pour la caractérisation rapide de levures isolées d'écosystèmes complexes. Au cours de ce travail, nous avons développé une méthode à la fois rapide et sensible pour l'identification des levures couramment isolées pendant l'affinage du fromage. Son principe repose sur l'hybridation de séquences spécifiques sur les préparations brutes d'ADN génomique des souches à identifier. Pour la construction des sondes, nous avons dû suivre plusieurs stratégies différentes: amplification de séquences disponibles dans les bases de données, clonage au hasard de séquences d'ADN génomique, isolement de séquences spécifiques obtenues par amplification RAPD d'ADN génomique ou par amplification d'ADNr. Après leur validation, les sondes ont pu être mises en œuvre

* Correspondence and reprints

E-mail: serge@grignon.inra.fr 
dans différentes applications. Elles ont été utilisées pour cribler 400 souches de levures isolées de différents fromages français. Les souches ayant été préalablement identifiées par des tests classiques, nous avons pu comparer les deux types de méthodes d'identification, moléculaire et conventionnelle. La sonde spécifique de $D$. hansenii a été testée avec succès dans des essais d'hybridation sur colonie. Au total, ces sondes se sont révélées être de bons outils pour le suivi et l'inventaire de la biodiversité des levures fromagères.

levures / fromage / identification moléculaire / hybridation / biodiversité

\section{INTRODUCTION}

Cheese making is probably one of the most ancient means used for milk preservation. It proceeds in 3 steps: curdling, draining of whey and ripening. The latter step consists of an enzymatic digestion of the curd constituents and it confers on cheeses their characteristic textures and flavors. Enzymes are already present in the milk and also provided by a complex flora comprising bacteria, molds and yeasts [17]. Yeasts stimulate the growth of bacteria by metabolizing lactic acid, producing NH3 and releasing vitamins and nutrients [10]. They contribute directly to the ripening process by providing proteolytic and lipolytic enzymes. They facilitate the growth and penetration of molds by opening up the texture of blue-veined cheeses. They are thought to contribute to the taste of cheese by providing specific flavors $[9,12,17,20]$. It is also reported that yeasts such as Debaryomyces hansenii inhibit the growth of spoilage bacteria of the genus Clostridium $[8,11]$.

Many yeast species are encountered in milk, dairies and brine but only a few of them are able to adjust to the cheese ecosystem. Yeast maintenance and development are very likely due to their ability to grow in the presence of salt at low temperature and/or to metabolize lactic and citric acids.

Several yeast species are associated with the ripening of cheese: D. hansenii, Kluyveromyces lactis, Kluyveromyces marxianus, Candida zeylanoides, Yarrowia lipolytica, Geotrichum candidum, Saccharomyces cerevisiae, Torulaspora delbrueckii, Pichia fermentans, and Pichia menbranaefaciens [5]. Their prevalence depends on the type of cheese considered. Texture and flavor development in cheese is linked to the proportion of each species present at a given time in connection with the biochemical activities of these microorganisms that develop at the surface or within the cheese.

Previous studies on yeast populations present in cheese were based on the identification of the species with conventional diagnostic testing $[2,3,20,25$, 26]. The use of morphological, physiological and biochemical criteria is timeconsuming. At least three weeks are required to identify yeast species following this approach, which also necessitates painstaking manipulation and laborious computing steps. It thus cannot be used for the systematic study of complex flora in cheese. Here, we constructed specific molecular probes that allow the species identification of hundreds of strains belonging to the predominant yeast 
species involved in cheese ripening in less than 2 weeks. The construction, validation and characteristics of these probes are reviewed. The probes were applied to the screening of a set of yeast strains isolated from various cheeses during processing.

\section{MATERIALS AND METHODS}

\subsection{Yeast strains, bacterial strains and growth conditions}

The reference strains used in this study are listed in Table I. Isolates were identified using the morphological and biochemical tests described $[1,14]$. Yeast cells were routinely grown in YPD (1\% yeast extract, $1 \%$ peptone, $1 \%$ glucose) at $28{ }^{\circ} \mathrm{C}$. Escherichia coli $\mathrm{DH} 5 \alpha$ cells were routinely grown in LB $(2 \% \mathrm{LB}$ Broth base, $0.5 \% \mathrm{NaCl}$ ) at $37^{\circ} \mathrm{C}$.

\subsection{DNA techniques}

Common DNA manipulations were as described previously [24]. Genomic DNA extractions for cloning were performed as described previously [23]. Rapid genomic DNA extraction was derived from a published method [13]. After 48-h cultivation in $10 \mathrm{ml}$ of YPD liquid medium, cells were washed and resuspended in $0.2 \mathrm{ml}$ of cell lysis buffer (10 mM Tris pH $8,1 \mathrm{mM}$ EDTA, $100 \mathrm{mM} \mathrm{NaCl}, 2 \%$ Triton, $1 \% \mathrm{SDS}$ ). $0.3 \mathrm{ml}$ phenol $/ \mathrm{CHCl}_{3}$ and $0.3 \mathrm{~g}$ of glass beads were added to the mixture and vortexed for $4 \mathrm{~min}$. Then $0.2 \mathrm{ml} \mathrm{TE}(10 \mathrm{mM}$ Tris $\mathrm{pH}$ $8,1 \mathrm{mM}$ EDTA) were added before $5 \mathrm{~min}$ centrifugation. Supernatant $(1.6 \mathrm{ml})$ was precipitated once in presence of $1 \mathrm{ml} 100 \%(\mathrm{~V} / \mathrm{V})$ ethanol. After $2 \mathrm{~min}$ centrifugation, the DNA pellet was washed with $1 \mathrm{ml} 70 \%(\mathrm{~V} / \mathrm{V})$ ethanol and dried quickly. Then it was resuspended in $200 \mu \mathrm{l}$ TE and incubated for $15 \mathrm{~min}$ at $37^{\circ} \mathrm{C}$ with $1 \mu \mathrm{l}$ of a $10 \mathrm{mg} / \mathrm{ml}$ RNase solution. For cloning, pBluescript ${ }^{\circledR}$ $\mathrm{SK}^{-}$(Stratagene) was digested to completion with $E c o \mathrm{RV}$ and its ends were dephosphorylated with alkaline phosphatase (Boehringer-Mannheim, Germany). The fragments were treated with a combination of the Klenow fragment of polymerase I and T4 DNA polymerase, to generate blunt ends, and were inserted into $\mathrm{pBluescript} \mathrm{SK}^{-}$.

\subsection{Electroporation}

DH5 $\alpha$ E. coli cells in the late exponential phase were prepared by washing 3 times in ice-cold $\mathrm{H}_{2} \mathrm{O}$. Glycerol (10\% final concentration) was added for the storage of the cells at $-80^{\circ} \mathrm{C}$. Cells were transformed by electroporation using a Bio-Rad Gene Pulser $\mathrm{II}^{\circledR}$ under the following conditions: 2,500 V, $100 \Omega$ 
and $25 \mu \mathrm{F}$. Cells were recovered with $1 \mathrm{ml} \mathrm{LB}$, incubated for 1 -h at $37{ }^{\circ} \mathrm{C}$ and plated out on $80 \mu \mathrm{g} \cdot \mathrm{ml}^{-1}$ ampicillin containing LB media.

\subsection{PCR amplification}

PCR amplifications with NL1 and NL4 primers were performed as described previously [4]. NL1 and NL4 primers, described in [21], are universal primers that are used to amplify the 5'end of the large subunit of the ribosomal RNA gene spanning the variable domains D1 and D2 (D1/D2 rDNA). For RAPD, we used conditions similar to those described [27] with the deca-primers of Operon Technology (USA). For the other PCR amplifications, yeast genomic DNA $(50 \mathrm{ng})$ was used as template under the following conditions: $4 \mathrm{~min}$ at $94{ }^{\circ} \mathrm{C}, 25 / 35$ cycles of $30 \mathrm{~s}$ at $94{ }^{\circ} \mathrm{C}, 30 \mathrm{~s}$ at the Tm required, 1 min per $\mathrm{kb}$ to be amplified at $72{ }^{\circ} \mathrm{C}$ followed by 5 min at $72{ }^{\circ} \mathrm{C}$, with 2.5 units of thermostable polymerase (Appligene, France) and 1.5 units of Pfu polymerase (Biolabs, USA) in the recommended buffer.

\subsection{Purification of PCR products}

PCR products for hybridization were separated in $0.6 \%$ Seaplaque (FMC, USA) low-melting agarose gels, excised in gel bands, and labeled. PCR products for sequencing were purified using the Qiaquick DNA purification kit (Qiagen, Germany), according to the manufacturer's recommendations.

\subsection{DNA/DNA hybridization}

Genomic DNA was deposited on GeneScreen nylon membrane (DuPont, USA). Membranes were incubated on top of a $0.1 \mathrm{M} \mathrm{NaOH} / 1.5 \mathrm{M} \mathrm{NaCl}$ solution for $1 \mathrm{~min}$, immersed in a $2 \times \mathrm{SSC} / 0.2 \mathrm{M}$ Tris $\mathrm{HCl} \mathrm{pH} 7.5$ solution for $1 \mathrm{~min}$ and air dried. DNA was linked to the membrane with UV-irradiation. DNA probes were prepared from plasmids by digestion or amplified by specific primers and purified after gel separation. They were labeled with $\left(\alpha^{-32} \mathrm{P}\right) \mathrm{dCTP}$ using the Megaprime labeling kit (Amersham, UK). DNA/DNA hybridizations were carried out overnight at $65^{\circ} \mathrm{C}$ in $0.5 \mathrm{M} \mathrm{Na}_{2} \mathrm{HPO}_{4} / 1 \mathrm{mM} \mathrm{EDTA} / 7 \%$ SDS buffer. Washing steps were $3 \times 5 \mathrm{~min}$ in $40 \mathrm{mM} \mathrm{Na}_{2} \mathrm{HPO}_{4} / 1 \%$ SDS followed by $2 \times 15 \mathrm{~min}$ in $0.1 \times \mathrm{SSC} / 0.1 \% \mathrm{SDS}$ buffer [6].

\subsection{Colony hybridization}

Colonies were transferred with toothpicks onto a Hybond $\mathrm{H}^{+}$membrane which was placed DNA side up on YPD agar medium. After 48-h cultivation, the membrane was treated with $(10 \mathrm{mM}$ Tris $\mathrm{pH} 8,1 \mathrm{mM}$ EDTA, $1 \mathrm{M}$ sorbitol, $3 \mathrm{mg} / \mathrm{ml} \mathrm{DTT}$ ) buffer for $10 \mathrm{~min}$. Protoplasts were made with a mixture of 
zymolyase and cytohelicase in the presence of sorbitol. Cells were lysed with $1 \mathrm{M} \mathrm{NaOH}$ for $10 \mathrm{~min}$. Membranes were neutralized with $0.5 \mathrm{M}$ Tris $\mathrm{pH} 7.5$, $1.5 \mathrm{M} \mathrm{NaCl}$ solution. DNA was linked to the membrane with UV-irradiation. DNA/DNA hybridizations were carried as described above. The probe was labeled with dioxigenin-dUTP according to the manufacturer's recommendations. Hybridization was revealed with $\mathrm{CSPD}^{\circledR}$.

\subsection{Sequencing}

DNA was sequenced on both strands essentially as described previously [19] with $200 \mathrm{ng}$ of PCR product and 4 pmols of primers. NL1 and NL4 primers are described in [21]. Sequences were compiled and analyzed using the Staden package [7] and FASTA [22] in the GCG environment (Genetics Computer Group, Madison, Wisconsin, USA).

\section{RESULTS AND DISCUSSION}

\subsection{Construction and validation of the DNA probes}

We constructed specific probes for the identification of the major yeast species present in cheese during the ripening process [5]. The strains utilized are listed in Table I. Except for Geotrichum candidum, the type strains of the other species were used.

Various strategies were adopted for the construction of probes. Whenever possible, probes were deduced from sequences available in databases. This was the case for Saccharomyces cerevisiae, Kluyveromyces marxianus, Kluyveromyces lactis and $G$. candidum. We designed specific primers and PCR-amplified parts of various genes: $C D C 15$ for $S$. cerevisiae (CDC15 is an essential gene and cannot be deleted), MIG1 for K. lactis and K. marxianus (these genes are orthologs and are sufficiently divergent in sequence to be species-specific) and LIP $\mathscr{2}$ for $G$. candidum (one of the few available genes of this species).

For most species, DNA sequences were not available. Probes were obtained after enzymatic digestion of genomic DNA and random cloning of 2 to $3 \mathrm{~kb}$ fragments. This method was utilized for Candida zeylanoides, Pichia guilliermondii, Pichia fermentans, Pichia anomala, Pichia menbranaefaciens and Zygosaccharomyces rouxii. A large number of $D$. hansenii strains were typed by RAPD. Some primers gave major amplification fragments of respectively $1.0 \mathrm{~kb}$ and $1.8 \mathrm{~kb}$ which were common to all the strains tested. These two fragments were isolated and cloned. They proved to be highly specific for D. hansenii when used as probes.

Yarrowia lipolytica and Torulaspora delbrueckii failed to hybridize with the probes developed by the methods described above. This could be due to the 
Table I. List of strains used for the construction of probes.

\begin{tabular}{|c|c|c|c|c|}
\hline $\begin{array}{l}\text { Strain } \\
\text { number }\end{array}$ & Species & $\begin{array}{l}\text { Other } \\
\text { collection }\end{array}$ & Origin & Country \\
\hline CLIB 199 & Candida zeylanoides $^{T}$ & CBS 619 & $\begin{array}{l}\text { Blastomycotic } \\
\text { macroglossia }\end{array}$ & \\
\hline CLIB 197 & $\begin{array}{l}\text { Debaryomyces hansenii }{ }^{T} \text { var. } \\
\text { hansenii }\end{array}$ & CBS 767 & Cherry & Denmark \\
\hline CBS 109-12 & Geotrichum candidum & & Milk & USA \\
\hline CLIB 196 & Kluyveromyces lactis $^{N T}$ & CBS 683 & Cheese & United Kingdom \\
\hline CLIB 282 & Kluyveromyces marxianus ${ }^{T}$ & CBS 712 & & \\
\hline CLIB 284 & Pichia anomala ${ }^{N T}$ & CBS 5759 & & USA \\
\hline CLIB 198 & Pichia fermentans ${ }^{T}$ & CBS 187 & Buttermilk & The Netherlands \\
\hline CLIB 186 & Pichia guilliermondii ${ }^{T}$ & CBS 566 & Sputum & Hungary \\
\hline CLIB 212 & Pichia membranaefaciens ${ }^{T}$ & CBS 107 & & \\
\hline CLIB 227 & Saccharomyces cerevisiae ${ }^{N T}$ & CBS 1171 & Beer & The Netherlands \\
\hline CLIB 230 & Torulaspora delbrueckii ${ }^{N T}$ & CBS 1146 & & \\
\hline CLIB 183 & Yarrowia lipolytica $^{T}$ & CBS 6124 & Maize-processing & USA \\
\hline CBS 732 & Zygosaccharomyces rouxii ${ }^{N T}$ & & $\begin{array}{l}\text { Concentrated plant } \\
\text { grape must }\end{array}$ & Italy \\
\hline
\end{tabular}

(T): type strain

(NT): neo-type strain. 
Table II. Strategies for the construction and the validation of specific probes.

\begin{tabular}{lcc}
\hline Strain & Type of probe & Type of validation \\
\hline Candida zeylanoides & 2 & A and B \\
Debaryomyces hansenii & 3 & A and B \\
Geotrichum candidum & 1 & A and B \\
Kluyveromyces lactis & 1 & A and B \\
Kluyveromyces marxianus & 1 & A and B \\
Pichia anomala & 2 & A and B \\
Pichia fermentans & 2 & A and B \\
Pichia guilliermondii & 2 & A and B \\
Pichia membranaefaciens & 2 & A and B \\
Saccharomyces cerevisiae & 1 & A and B \\
Torulaspora delbrueckii & 4 & A and B \\
Yarrowia lipolytica & 4 & A and B \\
Zygosaccharomyces rouxii & 2 & A \\
\hline
\end{tabular}

(1): sequence available in databases

(2): random cloning of 2 to $3 \mathrm{~kb}$ fragments

(3): characteristic fragment from RAPD amplification

(4): rDNA amplification (NTS or NTS2)

(A): validation of the inter-species specificity

(B): validation against strains belonging to the same species

DNA extraction procedure since we used a very crude and rapid method which enables us to treat a large number of strains. For $Y$. lipolytica and $T$. delbrueckii, we therefore PCR-amplified the NTS (Non-Transcribed Sequence) and NTS2 of ribosomal DNA, respectively. These sequences are naturally repeated in the genome and result in efficient probes whatever the concentration or purity of DNA preparations for hybridization.

Probes were then validated (Tab. II) by hybridization with genomic DNA deposited on filters (Materials and Methods). The probes were classified as specific when no positive signal was detected in hybridization experiments with the DNA of the other yeast species commonly found in cheese. Most of the probes were also tested against several strains of the same species isolated from various ecosystems (Tab. II). D. hansenii was submitted to a careful validation which also covered other species of the Debaryomyces genus.

We developed 14 DNA probes specific for the yeast species commonly isolated during cheese ripening. Their utilization combines rapidity, sensitivity and simplicity since 96 DNA samples can be deposited on the same membrane and several menbranes can be treated together. It is therefore possible to carry out the identification of hundreds of strains at a time. Nevertheless, genomic 
DNA preparation remains the limiting step of this method. The range of DNA concentrations for optimal hybridization conditions also has to be established.

\subsection{Screening of yeast strains isolated from the cheese and dairy environment}

The probes described above were used to screen 400 yeast strains isolated between the 70's and the 80 's $[2,20,25,26]$. This set of strains covers various cheese productions from distinct regions of France. Most isolates came from milk, from cheese at different steps of the processing or from the dairy environment. Some strains were isolated from the environment i.e. on cattle and feeds. Strains were previously identified according to Lodder [18] or following a simplified set of classical tests [3].

Genomic DNA of the 400 strains was prepared and deposited on Genescreen membrane. The membranes were successively hybridized with the radiolabeled probes developed in this work. The results are reported in Table III. 311 strains were unambiguously identified by hybridization. No cross-hybridization was observed with the different probes, indicating that the method is very specific.

A large database of the variable regions D1 and D2 of the DNA encoding the large subunit of the ribosomal RNA (D1/D2 rDNA) sequences from over 500 yeast species including 200 Candida spp., has been recently published $[15,16]$. This database is now widely used and was applied to identify the strains that gave either no signal or a very faint signal after hybridization. We used NL1 and NL4 primers to PCR-amplify over 550 bp of the D1/D2 rDNA [21] as described in Materials and Methods. The sequences of the PCR products were then compared to sequences present in the database. D1/D2 rDNA sequencing confirmed the identification of the strains that hybridized weakly to one of the probes (Tab. III). In addition, sequencing was systematically performed on both strands to avoid ambiguity.

We also unambiguously identified 17 strains that did not give any signal in hybridization. They belong to species not commonly found during cheese maturation [5]: Candida oeleophila, Candida sake, Candida pseudoglaebosa, Candida boidinii, Saccharomyces castellii, Debaryomyces castellii and Williopsis californica. We did not construct probes for these species since they are rarely present in cheese. Indeed, these strains, which belong to 7 species, represent only $4 \%$ of the strains screened, indicating that sequencing was more suitable for the analysis of this small sample. 27 strains remained unidentified by D1/D2 rDNA sequencing, indicating that these species are neither referenced nor described for the moment. Among them, four groups of respectively 2, 2, 3 and 6 strains exhibited the same D1/D2 rDNA sequence. The other sequences were unique. Interestingly, $60 \%$ of these unidentified strains were not directly isolated from cheese during processing. Sequence analysis will be described in a future report (Davila et al., manuscript in preparation). 
Table III. Identification of yeasts isolated from cheese and dairy at the species level.

\begin{tabular}{|c|c|c|}
\hline Strain & $\begin{array}{c}\text { Number of strains } \\
\text { detected by } \\
\text { hybridization }\end{array}$ & $\begin{array}{l}\text { Number of strains } \\
\text { identified with } \\
\text { D1/D2 sequencing }\end{array}$ \\
\hline \multicolumn{3}{|l|}{ Associated with cheese ripening } \\
\hline Candida zeylanoides & 23 & 0 \\
\hline Debaryomyces hansenii & 61 & 0 \\
\hline Geotrichum candidum & 0 & 0 \\
\hline Kluyveromyces lactis & 83 & $17^{(2)}$ \\
\hline Kluyveromyces marxianus & 63 & $12^{(2)}$ \\
\hline Pichia anomala & 0 & 0 \\
\hline Pichia fermentans & nd & 13 \\
\hline Pichia membranaefaciens & 0 & 0 \\
\hline Saccharomyces cerevisiae & 54 & $3^{(2)}$ \\
\hline Torulaspora delbrueckii & 5 & 0 \\
\hline Yarrowia lipolytica & 13 & 0 \\
\hline Zygosaccharomyces rouxii & 0 & 0 \\
\hline \multicolumn{3}{|l|}{ Opportunistic } \\
\hline$\overline{C a n d i d a}$ boidinii & nd & 1 \\
\hline Candida oeleophila & nd & 3 \\
\hline Candida pseudoglaebosa & nd & 1 \\
\hline Candida sake & nd & 2 \\
\hline Debaryomyces castellii & nd & 2 \\
\hline Pichia guilliermondii & 9 & 0 \\
\hline Saccharomyces castelli & nd & 6 \\
\hline Williopsis californica & nd & 2 \\
\hline$\underline{\text { Undetermined }}$ & $89^{(1)}$ & 27 \\
\hline$\underline{\text { Total }}$ & 400 & 89 \\
\hline
\end{tabular}

(1): weak signal or no signal in hybridization.

(2): weak signal in hybridization confirmed by D1/D2 rDNA sequencing $[15,16,21]$. (nd): not determined.

The comparison of molecular and conventional identification methods revealed some discrepancies. D. hansenii and S. cerevisiae gave a good convergence since $C$. famata is the anamorph of $D$. hansenii and $S$. italicus is a variety of $S$. cerevisiae. Most of the discrepancies were, however, due to the use of a simplified method of identification at the early stage of this project. It was shown that the method can be imprecise in some cases (Davila et al., 


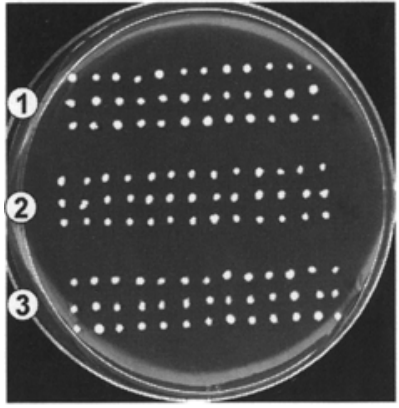

A

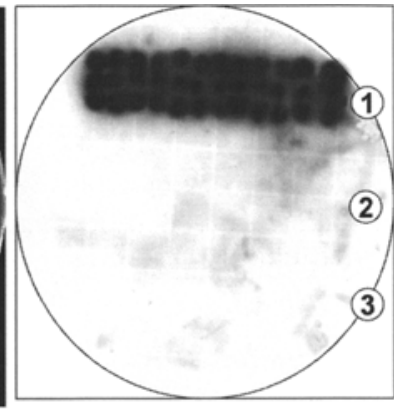

B

Figure 1. Colony hybridization with a probe specific for $D$. hansenii A: colonies on YPD agar medium; B: Hybond $\mathrm{H}^{+}$replicate, dioxigenin-dUTP labeling, $\mathrm{CSPD}^{\circledR}$ detection; 1: D. hansenii colonies; 2: S. cerevisiae colonies; 3 : K. lactis colonies. Note that the film was largely over-exposed to ensure that no aspecific hybridization could be detected.

manuscript in preparation). For instance, $12 \%$ of the $K$. marxianus strains were mixed up with other species of the Kluyveromyces genus in conventional identification. Real discrepancies, evidenced by a complete conventional identification $[1,18]$, were in fact very rare and could not be solved. This is a problem due to the set-up of this new molecular method. Universal and systematic use of D1/D2 sequencing will help to redefine species.

A relevant number of strain species identified by hybridization were tested with D1/D2 sequencing. Their identification was always confirmed, indicating the accuracy of our method.

\subsection{Colony hybridization}

One of the two specific probes for D. hansenii [7] was tested in colony hybridization experiments. Thirty six D. hansenii, S. cerevisiae and K. lactis colonies were deposited on solid medium, grown and transferred onto Hybond membrane. Cells were lysed and DNA was bound to the membrane as described in Materials and Methods. As shown in Figure 1, the probe hybridized to all $D$. hansenii replicates but not to $S$. cerevisiae or $K$. lactis ones. The colony hybridization methodology seems even more suitable for the identification of large number of strains as it eliminates the genomic DNA preparation step.

\subsection{Concluding remarks}

The study of complex flora by classical diagnostic tests is very painstaking and time-consuming. In this work, we review the development of specific probes for an identification of yeasts which combines simplicity, rapidity and 
accuracy. These probes were successfully utilized to identify at the species level 400 yeast strains. Furthermore, D. hansenii-specific probes could be used in colony hybridization experiments. These probes had proved to be efficient tools for the analysis of yeast species biodiversity. This method could be improved by using a mixture of probes labeled with different fluorescent dyes to reduce the number of hybridizations.

\section{ACKNOWLEDGEMENTS}

Annie Auger and Andrée Lepingle are gratefully acknowledged for sequencing. This work was supported by a grant from the Bureau des ressources génétiques. Mauricio Corredor was supported by a fellowship from the French ministère des Relations Extérieures.

\section{REFERENCES}

[1] Barnett J.A., Payne R.W., Yarrow D., Yeasts: characteristics and identification, 2nd ed. Cambridge University Press, Cambridge, 1990.

[2] Baroiller C., Schmidt J.L., Contribution à l'étude de l'origine des levures du fromage de Camembert, Lait 70 (1990) 67-84.

[3] Baroiller C., Schmidt J.L., Mise au point d'une grille simplifiée d'identification des principales espèces de levures présentes dans les fromages, Lait 64 (1984) $16-28$.

[4] Casaregola S., Nguyen H.V., Lepingle A., Brignon P., Gendre F., Gaillardin C., A family of laboratory strains of Saccharomyces cerevisiae carry rearrangements involving chromosomes I and III, Yeast 14 (1998) 551-564.

[5] Choisy C., Desmazeaud M., Gueguen M., Lenoir J., Schmidt J.L., Tourneur C., L'affinage du fromage. Les phénomènes microbiens, in: Le fromage, $3 \mathrm{e}$ éd. Tec. \& Doc., Lavoisier, Paris, 1997, pp. 377-446.

[6] Church G.M., Gilbert W., Genomic sequencing, Proc. Natl. Acad. Sci. USA 81 (1984) 1991-1995.

[7] Corredor M., Davila A.-M., Gaillardin C., Casavegola S., DNA probes specific for the yeast species Debaryomyces hansenii: useful tools for rapid identification, FEMS Microbiol. Lett. 193 (2000) 171-177.

[8] Dear S., Staden R., A sequence assembly and editing program for efficient management of large projects, Nucleic Acids Res. 19 (1991) 3907-3911.

[9] Deiana P., Fatichenti F., Farris G.A., Mocquot G., Lodi R., Todesco R., Cecchi L., Metabolization of lactic and acetic acids in Pecorino Romano cheese made with a combined starter of lactic acid bacteria and yeast, Lait 64 (1984) 380-394.

[10] Devoyod J.J., Yeasts in cheese-making, in: Spencer J.F.T., Spencer D.M. (eds.), Yeast technology, Springer-Verlag, Berlin, 1990, pp. 228-240.

[11] Devoyod J.J., Desmazeaud M., Les associations microbiennes dans le fromage de Roquefort. III. Action des entérocoques et des levures fermentant le lactose vis-à-vis des lactobacilles, Lait 51 (1971) 399-415. 
[12] Fatichenti F., Bergere J.L., Deiana P., Farris G.A., Antagonistic activity of Debaryomyces hansenii towards Clostridium tyrobutyricum and $\mathrm{Cl}$. butyricum, J. Dairy Res. 50 (1983) 449-457.

[13] Fleet G.H., Yeasts in dairy products, J. Appl. Bacteriol. 68 (1990) 199-211.

[14] Hoffman C.S., Winston F., A ten-minute DNA preparation from yeast efficiently releases autonomous plasmids for transformation of Escherichia coli, Gene 57 (1987) 267-272.

[15] Kreger-van Rij N.J.W., The yeasts: a taxonomic study, 3rd ed., Elsevier Science Publishers, Amsterdam, 1984.

[16] Kurtzman C.P., Robnett C.J., Identification and phylogeny of ascomycetous yeasts from analysis of nuclear large subunit (26S) ribosomal DNA partial sequences, Antonie Van Leeuwenhoek 73 (1998) 331-371.

[17] Kurtzman C.P., Robnett C.J., Identification of clinically important ascomycetous yeasts based on nucleotide divergence in the 5' end of the large-subunit (26S) ribosomal DNA gene, J. Clin. Microbiol. 35 (1997) 1216-1223.

[18] Lenoir J., Lamberet G., Schmidt J.L., Tourneur C., La maîtrise du bioréacteur fromage, Biofutur 41 (1985) 23-50.

[19] Lodder J., The yeasts. A taxonomic study, 2nd ed., North Holland Publishing Company, Amsterdam-London, 1970.

[20] Maftahi M., Nicaud J.M., Levesque H., Gaillardin C., Sequencing analysis of a $15.4 \mathrm{~kb}$ fragment of yeast chromosome XIV identifies the RPD3, PAS8 and KRE1 loci, five new open reading frames, Yeast 11 (1995) 567-572.

[21] Nahabieh F., Schmidt J.L., Contribution à l'étude de la flore levure de quelques grands types de fromages de chèvre, Lait 70 (1990) 325-343.

[22] O'Donnell K, Fusarium and his near relatives, in: Reynolds D. J., Taylor W. (eds), The fungal holomorph: mitotic, meiotic and pleiomorphic speciation in fungal systematics, C. A. B. international, Wallingford, 1993, pp. 225-233.

[23] Pearson W.R., Lipman D.J., Improved tools for biological sequence comparison, Proc. Natl. Acad. Sci. USA 85 (1988) 2444-2448.

[24] Romano A., Casaregola S., Torre P., Gaillardin C., Use of RAPD and mitochondrial DNA RFLP for typing of Candida zeylanoides and Debaryomyces hansenii yeast strains isolated from cheese, System. Appl. Microbiol. 19 (1996) 255-264.

[25] Sambrook J., Fritsch E., Maniatis T., Molecular cloning: a laboratory manual. Cold Spring Harbor Laboratory Press, Cold Spring Harbor, New York, 1989.

[26] Schmidt J.L., Lenoir J., Contribution à l'étude de la flore levure du fromage de Camembert [II], Lait 60 (1980) 272-282.

[27] Schmidt J.L., Lenoir J., Contribution à l'étude de la flore levure du fromage de Camembert. Son évolution au cours de la maturation, Lait 58 (1978) 355-370.

[28] Williams J.G., Kubelik A.R., Livak K.J., Rafalski J.A., Tingey S.V., DNA polymorphisms amplified by arbitrary primers are useful as genetic markers, Nucleic Acids Res. 18 (1990) 6531-6535. 